\title{
An investigation of the deforming layer/debris-rich basal- ice continuum, illustrated from three Alaskan glaciers
}

\author{
JANE K. HART \\ Department of Geography, University of Southampton, Southampton SO9 5NH, England
}

\begin{abstract}
Three small Alaskan glaciers with different bed conditions were studied: Exit Glacier had a thin deforming layer and produced subglacial and proglacial glaciotectonic land forms; Childs Glacier also had a thin deforming layer but the upper part was frozen to the ice; Matanuska Glacier had no deforming layer but had subglacial debris-rich ice. Since it has been shown that sediment at the base can account for the majority of ice movement, it is suggested that there is a deforming bed/debris-rich continuum whereby similar processes occur throughout the different subglacial environments. These include: similar longitudinal deformation patterns (compression at the margin, extension and simple shear up-glacier); similar vertical deformation patterns, increase in deformation (and fabric strength) upwards through the sequence (leading to the attenuation of stratified ice into dispersed ice); and similar and interrelated incorporation processes. The major differences were that the processes occurred at a much faster rate within the deforming layer and that probably only the deforming layer will be recorded in the geological record.
\end{abstract}

\section{INTRODUCTION}

Over recent years there have been many investigations of both the glaciology (Boulton and Jones, 1979; Alley and others, 1986; Boulton and Hindmarsh, 1987) and the sedimentology (Hart and Boulton, 1991; Hicock and Dreimanis, 1992) of the deforming-bed model. This model proposes that, when a glacier moves over an unconsolidated sediment, there is a coupling between the glacier and the underlying bed, which results in a lowering of slope angle and/or increase in velocity of the ice sheet and deformation in the underlying sediment. This subglacial sediment deformation has begun to be studied in detail and its effects on the till sedimentation have been reported (e.g. Hart, 1994; Hart and Roberts, 1994).

However, studies have also been made on the deformation of ice (e.g. Hudleston, 1983; Knight, 1992; Sharp and others, 1994) and Tison and others (1993) suggested that "the study of the basal-ice layer (BIL) ... is the the key to understanding the mechanisms operating at the bed rock interface". However, there have been few attempts to link the ice sheet and sediment deformation together. Boulton (1979) showed that at Breidamerkurjökull, approximately $90 \%$ of the glacier movement occurs within the subglacial deforming bed. However, parallel studies on the debris-rich BIL have shown that these can also be a significant part of ice movement. Echelmeyer and Zhongxiang (1987) showed that the deformation of a frozen subglacial sediment accounted for over $60 \%$ of the motion within a $36 \mathrm{~cm}$ thick ice zone of Urumqi Glacier No. 1, and Brugman (1983), from a study of the glaciers in the Mount St. Helen area, also reported that deformation in the BIL was the main mode of ice flow. Thus, it appears that sediment at the base of the glacier, whether it is in the saturated deforming layer, a frozen subglacial layer or the debris-rich base of the ice, may be the most significant part of ice movement. In this paper, the subglacial environments of three Alaskan glaciers with different subglacial bed conditions are investigated and an attempt is made to describe and model a debris-rich basal-ice/subglacial sediment deformation continuum.

\section{SEDIMENTOLOGY}

Alaska has over 100000 glaciers (Post and Meier, 1980), which cover about $5 \%$ of Alaska's land area (Péwé, 1975). These are fed by moist, North Pacific air masses that move northwards from the Gulf of Alaska Calkin, 1988). The three glaciers investigated in detail were Exit Glacier, Childs Glacier and Matanuska Glacier (Fig. 1). These are three relatively low-altitude valley glaciers, found in the southern central part of Alaska. A description of these glaciers will follow.

At two of the sites clast-fabric analysis was carried out either in the frozen debris-rich layers in the base of the ice or in the frozen part of the deforming layer. At each site, a minimum of 25 clasts with an axial ratio greater than 1.5:1 were sampled. The initialized eigenvalues were then calculated. These eigenvalues (S1, S2 and S3) summarize fabric strength along the three principal directions of clustering (after Mark, 1973; Dowdeswell and Sharp, 1986). A fabric with no preferred orientation (weak fabric) would have equal eigenvalues, whilst a 


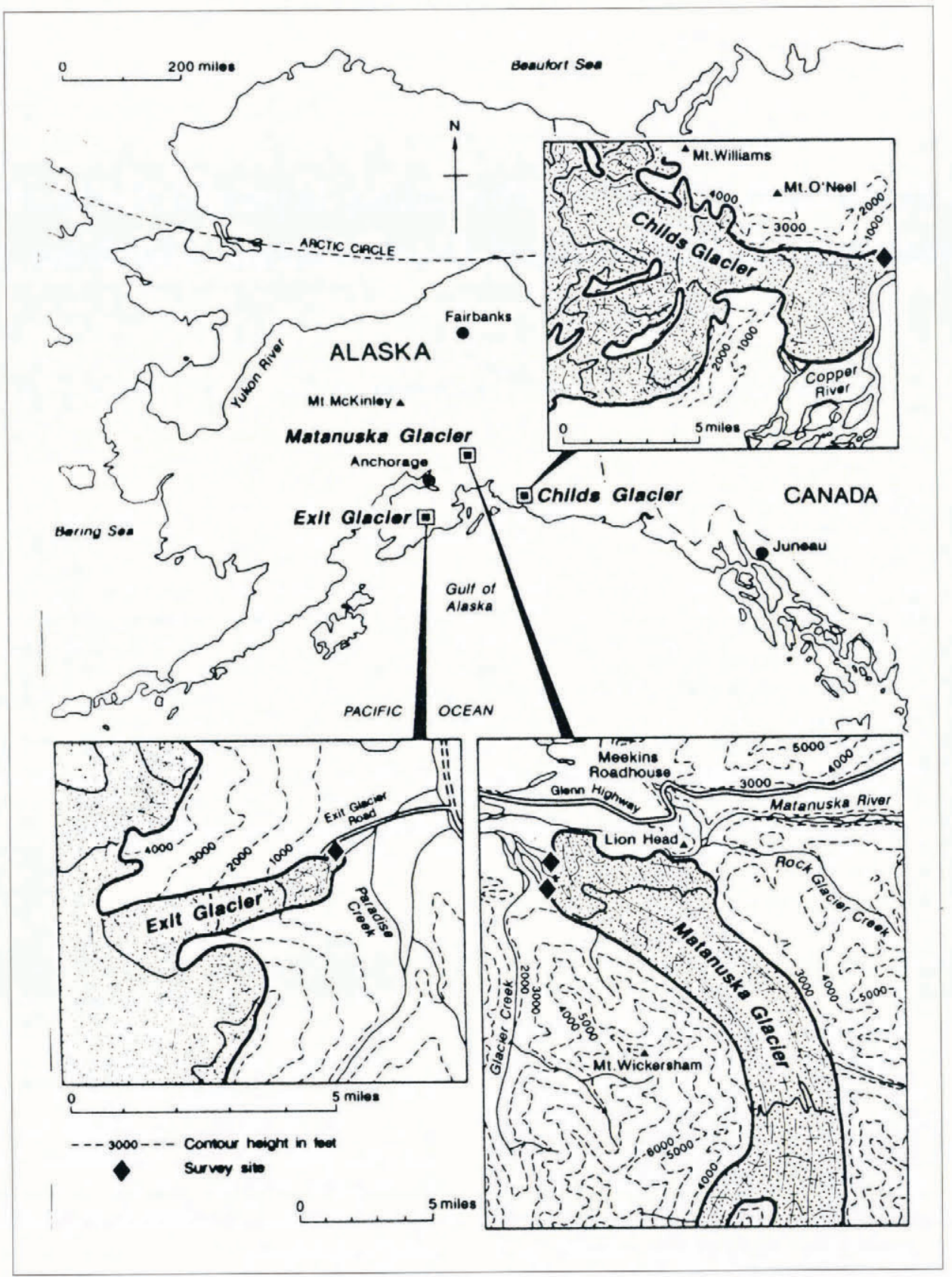

Fig. 1. Location map of the three Alaskan glaciers.

strong fabric would have a high value in the direction of maximum clustering $(\mathrm{S} 1)$ which is usually the direction of tectonic transport, and a low value in the direction of least clustering (S3).

\section{Exit Glacier}

This is a small glacier (approx. $5 \mathrm{~km}^{2}$ ) that drains the eastern side of the Harding Icefield, which is a large ice cap in the Kenai Fjords area (Fig. 1). The summit of the Harding Icefield is at $1700 \mathrm{~m}$ and Exit Glacier flows down the ice plateau at $900 \mathrm{~m}$, down to $120 \mathrm{~m}$ in the valley. The bedrock beneath the glacier is flysch of the Chugach Terrane (Connor and O'Haire, 1988). The Holocene marginal fluctuations of this glacier have been studied by Wiles and Calkin (1994), who recorded the Little Ice Age maximum moraine $($ age $=\mathrm{AD} 1825)$ approximately $2 \mathrm{~km}$ in front of the 1990 ice margin; and some ice-velocity measurements in the central part of the glacier were made by Rice (1975), who recorded velocities of $51 \mathrm{~cm} \mathrm{~d}^{-1}$.

The present-day glacier front stretches for approximately $1 \mathrm{~km}$ and consists of a series of fresh non-vegetated moraines overlying an outwash plain. Local observers (personal communication from M. Tetreau) have recorded that the glacier has been re-advancing since 1989 (40 m between 1989 and 1991). The surface of the glacier is relatively steep with large crevasses but it is clean (Fig. 2a). There is also a sharp junction between the underlying sediments and the ice; the basal ice is debrisfree and there is a saturated debris layer beneath. This debris layer is about $40 \mathrm{~cm}$ thick and is being currently extruded from beneath the ice. The median grain-size of this material is $1 \mathrm{~mm}$. I suggest that this layer is the deforming layer and I shall provide further reasons for this assertion below.

The resultant land forms at Exit Glacier can be 

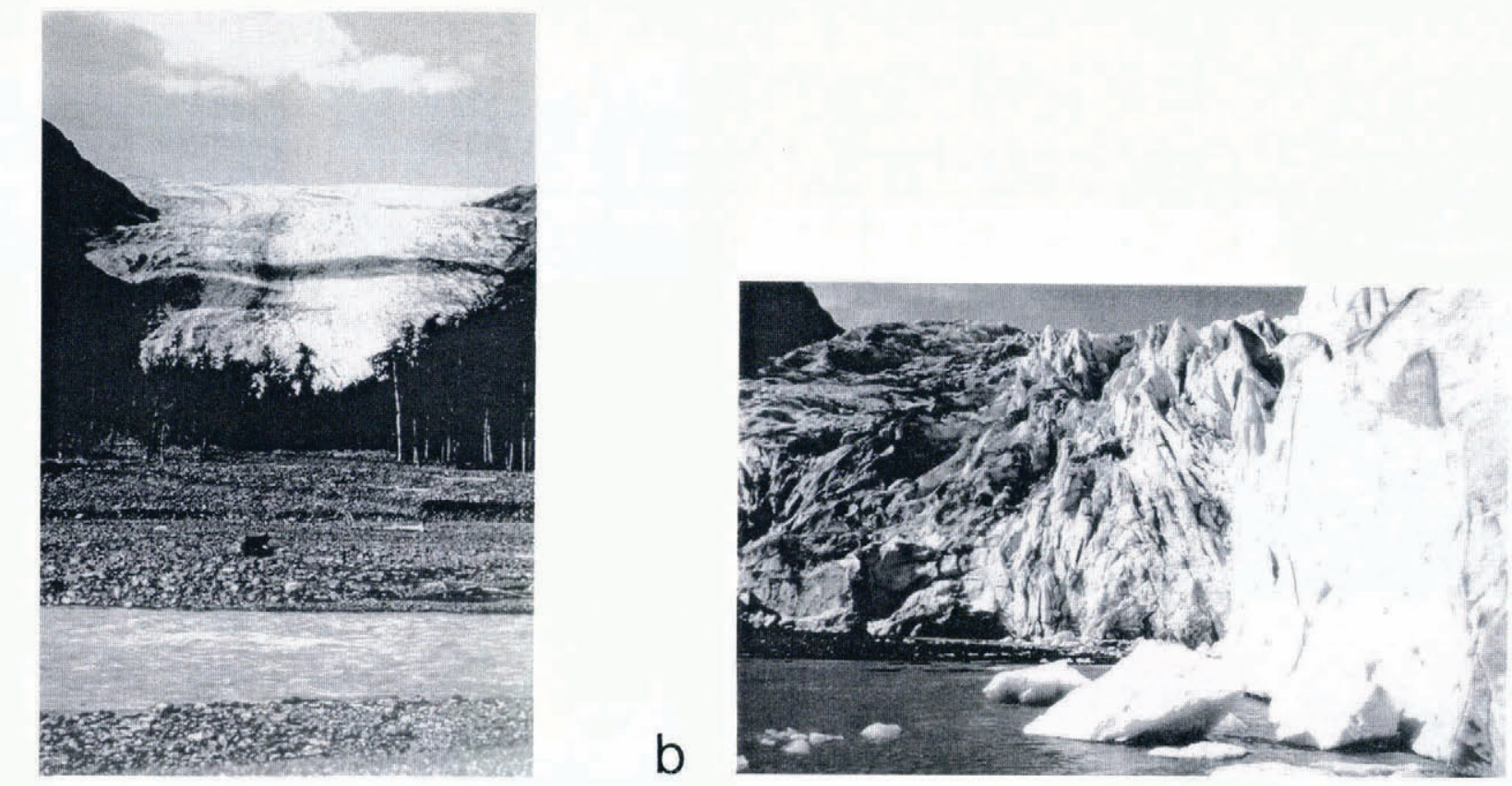

\section{a}

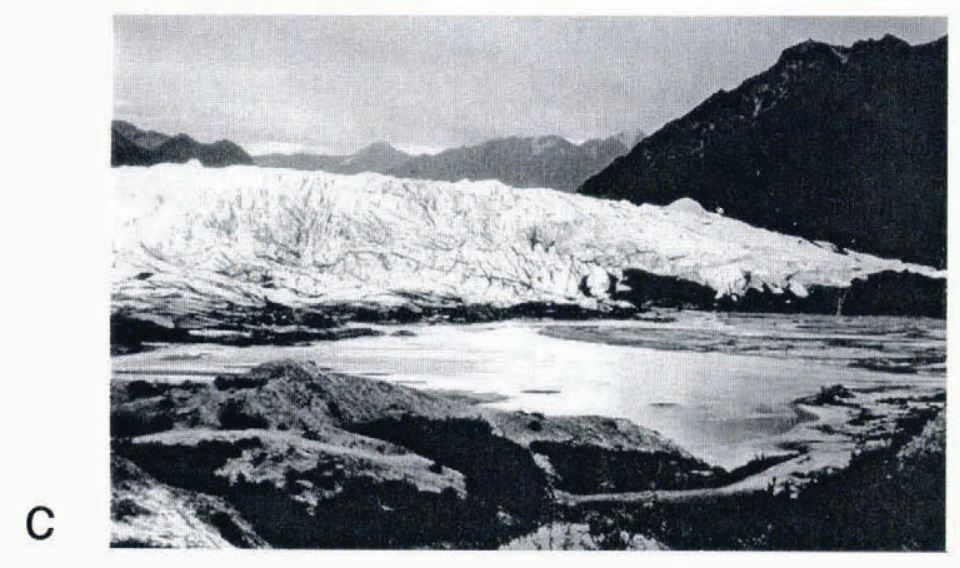

Fig. 2. Photographs of the glaciers: (a) Exil Glacier; (b) Childs Glacier; (c) Matanuska Glacier.

divided into proglacial and subglacial features which I shall discuss in turn. The end moraines at the margin of this glacier must be push moraines because (a) there is no supraglacial source of debris and (b) material was observed being extruded from beneath the glacier to form the moraines (Fig. 3a and c). These moraines have a steep distal slope of $45^{\circ}$ and a shallower proximal slope of $34^{\circ}$. The maximum height of the moraines is $5 \mathrm{~m}$ but they have built up into a moraine complex (see Fig. 3b), where a number of moraines are found. These may be annual pushes.

Where the ice has melted back in 1994, the year of this study, subglacial surfaces have been preserved (Fig. 3d and e). One of these reveals a series of small parallel ridges (20 $\mathrm{cm}$ high by $30 \mathrm{~cm}$ wide) with a large clast within the intervening furrow. Another common feature beneath the ice are flutes (Fig. 3f and $g$ ). These consist of slightly higher and wider ridges $(20-40 \mathrm{~cm}$ high by $30-60 \mathrm{~cm}$ wide), which run parallel with the ice flow and join the push moraines. Although only the distal parts of these flutes were exposed, it could be seen that they were composed of saturated till and were separated by ice tongues.

A final feature consisted of crevasse infilling on the glacier surface, which included circular, arcuate and linear ridges (Fig. 3i). These crevasses were filled with subglacial material.

\section{Interpretation}

The features seen at this glacier are very similar to those recorded in Iceland where the glaciers are lying over deformable sediments, e.g. Breidamerkurjökull Boulton, 1979) and Fjallsjökull (Sharp, 1984). The push moraines are formed by the movement of the subglacial deforming layer to the front of the glacier, so that the moraines are formed by a combination of extrusion and lateral pushing (Price, 1970; Sharp, 1984; Boulton, 1986; Hart, 1990).

It has been suggested by Boulton (1976) that flutes form due to the presence of larger clasts producing cavities into which saturated till flows. In this study, the proximal ends of the flutes were not exposed; however, the distal ends revealed the presence of ice tongues. It is suggested that these flutes formed as a result of saturated till moving into the low-pressure areas behind clasts. On the subglacial surface, this process could be seen on a larger scale, whereby a clast was probably dragged along by the ice producing a prow in front of it and a furrow behind. This is very similar to the small-scale subglacial lineations described by Hart (1995) from Vestari-Hagafellsjökull, central Iceland, which were also associated with a deforming bed. 


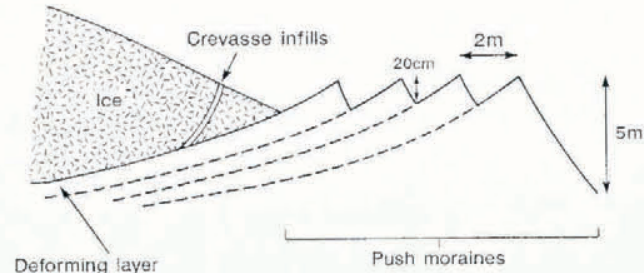

a

b

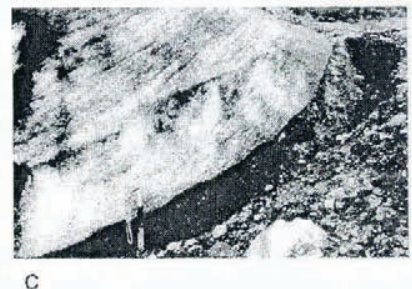

c

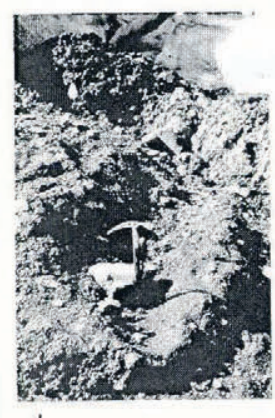

d

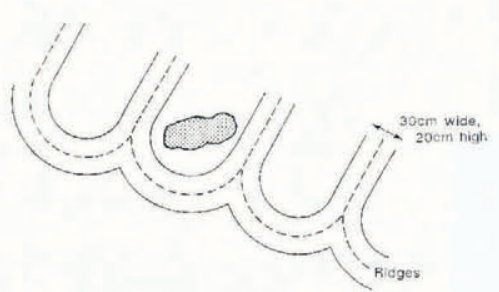

e
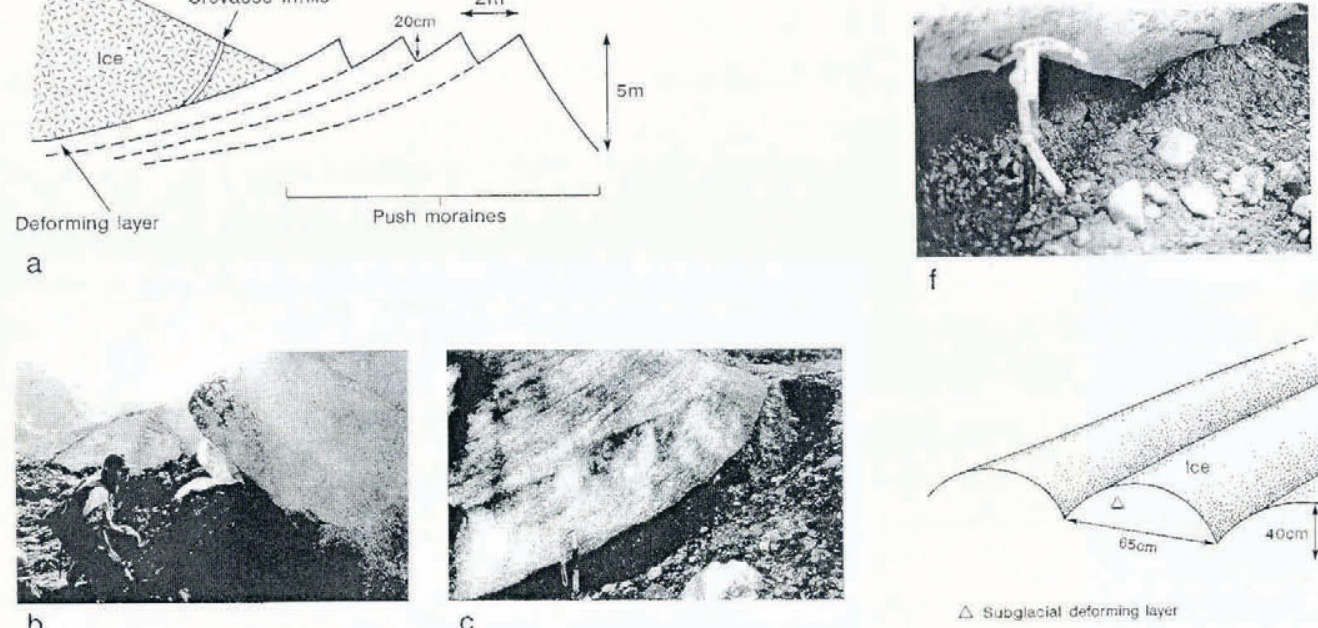

$f$

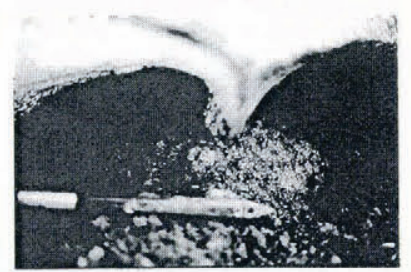

g

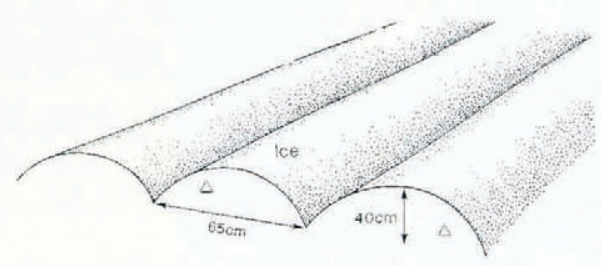

$\triangle$ Subglacial detorming layer

h

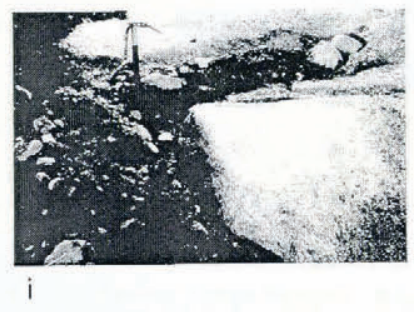

Fig. 3. Exit Glacier. (a) Schematic diagram showing the proglacial and subglacial marginal area; (b) Photograph of the push moraines; (c) Photograph of the deforming layer; (d) Photograph of the recently exposed subglacial surface; (e) Schematic diagram of the subglacial surface; $(f)$ and $(g)$ Photographs of flutes beneath the glacier; $(h)$ Schematic diagram of the flutes; (i) Crevasse infills.

The final features are crevasse infilling. I suggest these are filled by subglacial material as the saturated deforming layer flows up into the base of the crevasses. These have been described before (Sharp, 1988; Boulton and others, 1989) but not when associated with a nonsurging glacier.

Thus, at this site there is evidence for proglacial (push moraines), subglacial (flutes and lineations) and dead-ice (crevasse infillings) glaciotectonic deformation (Hart and Boulton, 1991). These occur in association with a $40 \mathrm{~cm}$ thick (at the margin) deforming layer. If it is assumed that these push moraines were formed in 4 years (since the observed re-advance), and that the push moraines were formed by debris beneath the glacier (as the glacier advances over an older outwash surface) being "squeezed out" at the margin, then an estimation of the maximum sediment flux can be produced. The total volume of push moraine over a $1 \mathrm{~m}$ section is $19.8 \mathrm{~m}^{3}$; this implies an annual sediment accumulation of $4.95 \mathrm{~m}^{3}$ year $\mathrm{m}^{-1}$.

\section{Childs Glacier}

This is a larger glacier (approx. $100 \mathrm{~km}^{2}$; Ferguson, 1992) that flows down the eastern side of the western Chugach Mountains (Fig. 1). The local summit in the area is Mount Williams at $1967 \mathrm{~m}$ and Childs Glacier flows down from $1430 \mathrm{~m}$ to almost sea level in the Copper River valley. The glacier flows out into a piedmost lobe in the valley and is unusual because the central part of the ice front is currently being undercut by the Copper River. This results in dramatic calving into the river and a steep ice front, $75-90 \mathrm{~m}$ high. The bedrock in this area is the early Cretaceous flysch of the Chugach Terrane (Connor and O'Haire, 1988).

The ice front investigated in this study was in the northern part, where the glacier terminates on land. This section stretches for approximately $1 \mathrm{~km}$ and also consists of a series of fresh non-vegetated moraines overlying an outwash plain and a series of older vegetated moraines. The surface of the glacier is at a relatively low angle but the surface is relatively clean and is cut by large crevasses (Fig. 2b).

Figure $4 \mathrm{a}$ shows a schematic cross-section of the marginal zone. Beneath the glacier there is a thin basal debris-rich frozen layer $(10-30 \mathrm{~cm}$ thick) and a $10-50 \mathrm{~cm}$ thick saturated debris layer beneath. The debris-rich frozen layer has a sharp upper junction with clean ice but was thawing at its junction with the deforming layer (Fig. $4 \mathrm{~b})$. The concentration of the debris in this frozen layer is $92 \%$ by weight and the grain-size was $0.5 \mathrm{~mm}$. A till fabric was also taken in the frozen debris which yielded results of $\mathrm{S} 1=0.697$ and $\mathrm{S} 3=0.036$ (mean orientation $248^{\circ}$, dip $2^{\circ}$ ) (Fig. 4a). In places it can be seen that the debris-rich layer is being sheared up into the main body 

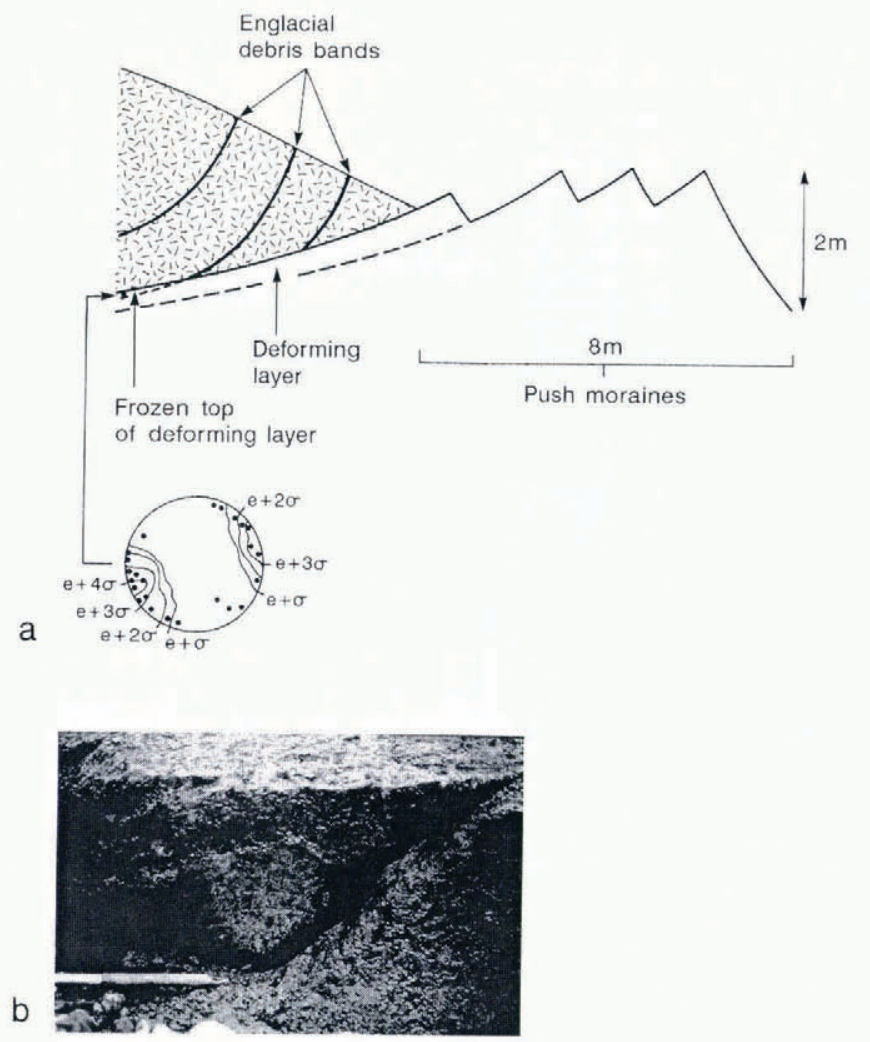

\section{c}

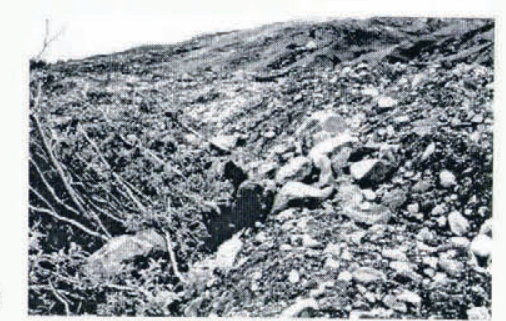

Fig. 4. Childs Glacier. (a) Schematic diagram of the proglacial and subglacial marginal area; (b) Photograph of the frozen top of the deforming layer beneath the glacier being sheared up into an englacial debris band; (c) Photograph showing the trees that have collapsed due to proglacial deformation.

of the ice to form englacial debris bands (Fig. 4a and b).

The saturated debris layer is being extruded from the glacier in a way similar to that seen at Exit Glacier. This subglacial layer is composed of well-rounded clasts, whilst the majority of the supraglacial material is far more angular. It can be seen that the glacier is in fact overrunning a previous outwash surface and that accounts for the roundness of the clasts.

In front of the ice is a series of small push moraines. These are unconsolidated and consist of three main ridges. These moraines are very recent as they have overrun trees (Fig. 4c). Thus, I suggest these represent three annual advances and show a recent re-advance similar to that seen at Exit Glacier.

\section{Interpretation}

I suggest that the end moraines represent push moraines formed in a way similar to those at Exit Glacier, by longitudinal sediment movement and proglacial pushing. I also suggest that the subglacial saturated debris layer is the deforming layer. The debris-rich basal layer appears to be the upper part of the deforming layer that has frozen to the base of the glacier.

If it is assumed that these push moraines were formed in 3 years, then an estimation of the sediment flux can also be produced. The total volume of push moraine over a $1 \mathrm{~m}$ section is $9 \mathrm{~m}^{3}$; this implies an annual sediment accumulation of $3 \mathrm{~m}^{3}$ year $\mathrm{m}^{-1}$.

\section{Matanuska Glacier}

This is the largest of the three glaciers studied (approx. area $320 \mathrm{~km}^{2}$; Ferguson, 1992) and it flows down the northern side of the western Chugach Mountains along a long valley (over $30 \mathrm{~km}$ long; Fig. 1). The glacier flows from close to the summit of Mount Marcus Baker $(4016 \mathrm{~m}$ ) down to $500 \mathrm{~m}$ in the valley. The glacier starts on Chugach Terrane flysch sediments but flows on to Tertiary sediments Chickaloon Formation of mudstones, sandstones and conglomerates; Connor and O'Haire, 1988) at its margin.

The ice margin is approximately $7 \mathrm{~km}$ across and mostly covered, particularly on the northern side, by supraglacial debris. The surface of the glacier is relatively flat with large crevasses (Fig. 2c). The area in front of the glacier consists of series of moraines and the ice front has been reported as being relatively stable over the last century. This glacier has been made famous by the work of Lawson (1979b, 1982) on the active proglacial sediment gravity flows and the debris-rich ice (BIL).

At the base of the glacier there is an $8 \mathrm{~m}$ thick unit of debris-rich ice (BIL). This has a very sharp upper boundary with clean ice, although the lower boundary was not exposed, but there was no evidence of any sediment being extruded from beneath the glacier. At Matanuska Glacier, two sites were studied in detail which I will discuss in turn.

Site 1. Figure 5 shows a schematic section of the site, a cross-section and ice $\log$. Because this is at the margin of the glacier the ice is dipping at $40^{\circ}$. The cross-section consists of two small moraines about $0.5 \mathrm{~m}$ high in front of the steep ice margin. These moraines consist of faulted laminated sands, silts and clays and also fine-grained diamicton (Fig. 5f). The inner moraine is separated from the steep glacier margin by $1 \mathrm{~m}$ (Fig. 5d). Presumably, the inner moraine marks the last winter limit of the margin. During the summer, active melting has produced high quantities of water and debris from the BIL and the supraglacial sediments. This has led to the development of debris flows discussed in detail by Lawson (1979b, 1982), which become trapped between the moraine and the ice. In this area there are also small lakes, marginal rivers and (dangerous!) pools of liquified mud (Fig. 5e). In places there is also a third, very small moraine $(0.3 \mathrm{~m}$ high), which is found between the ice margin and last winter's moraine.

In order to investigate the origin of the moraines, a study of particle shape was undertaken. At each site, 50 clasts were measured and both the lengths of the three axes and the overall roundness (angular, semi-angular, semi-rounded, round) recorded. The samples were taken from the supraglacial environment (Mat 1), the BIL 

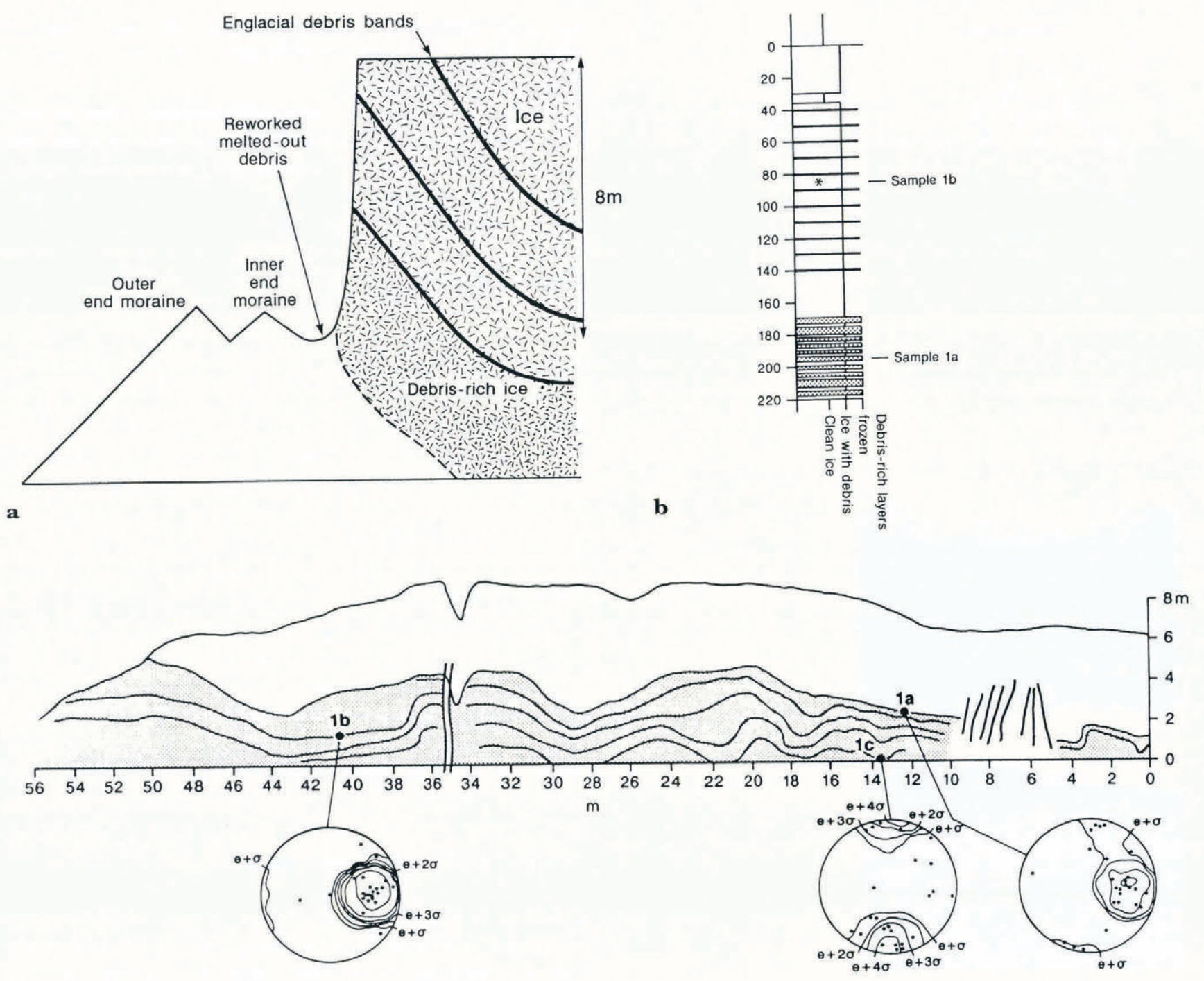

c
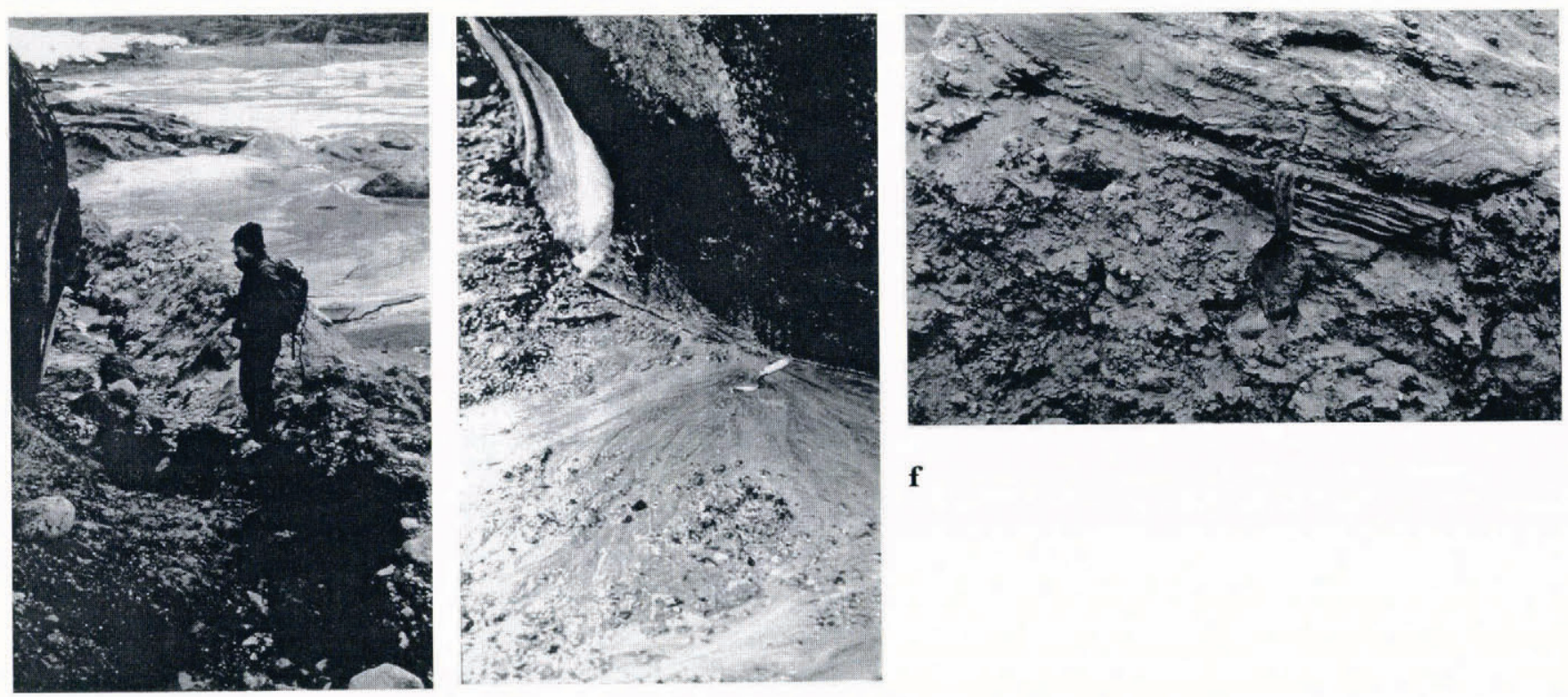

f

d

$\mathbf{e}$

Fig. 5. Matanuska Glacier. Site 1: (a) Schematic section of the marginal area; (b) Ice-facies log taken at $35 \mathrm{~m}$ along the horizontal scale on Figure $6 b ;(c)$ Cross-section of the debris-rich ice (shaded), with the ice fabrics shown; the samples shown here were for grain-size and debris concentration; (d) Photograph of the ice front and the moraine; (e) Photograph of the sedimentation occurring at the ice margin; $(f)$ Photograph of the deformed fine-grained material in the moraine. 
Hart: Investigation of deforming layer/debris-rich basal-ice continuum

(Mat 4), and the inner (Mat 2) and outer (Mat 3 moraine. The results are plotted on a triangular graph using the technique of Sneed and Folk (1958) and Benn and Ballantyne (1993) (Fig. 6) and the values for $\mathrm{C}_{40}$ (percentage of clasts with $c: a$ axes ratio of less than or equal to 0.4 ) and RA (percentage of very angular and angular clasts) were calculated (Table 1).

The supraglacial material consisted mostly of a combination of oblate- and prolate-shaped clasts with a high $\mathrm{C}_{40}$ value. In contrast, the debris-rich material was more spherical with the lowest $\mathrm{C}_{40}$ value. The two morainic samples had both an intermediate shape and $\mathrm{C}_{40}$ value, although closer to that of the debris-rich ice sample. Only the supraglacial sample had a non-zero value of RA.

The schematic ice diagram (Fig. 5c) shows that there are a number of open folds within the debris-rich ice,

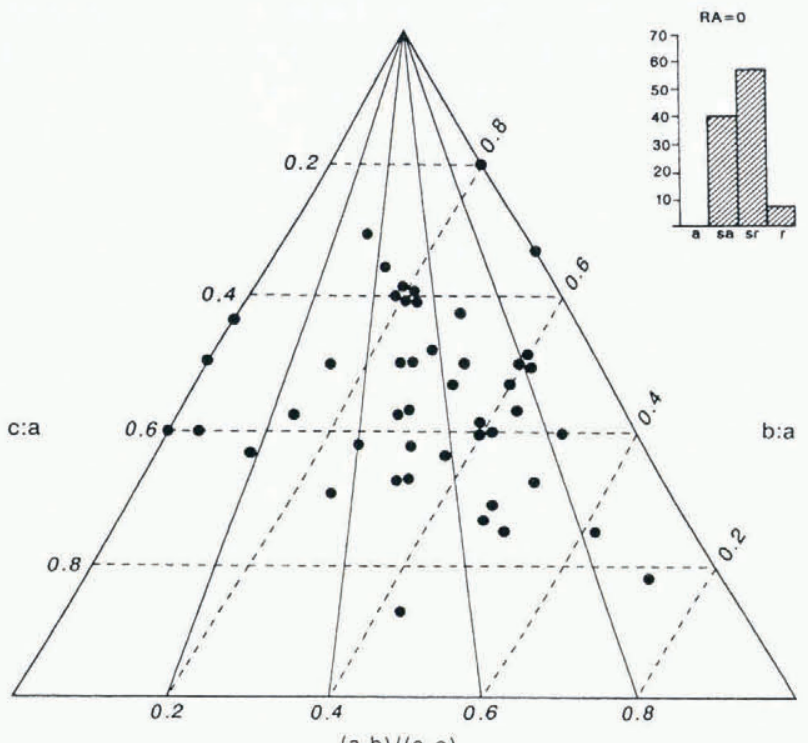

$(a-b) /(a-c)$

a

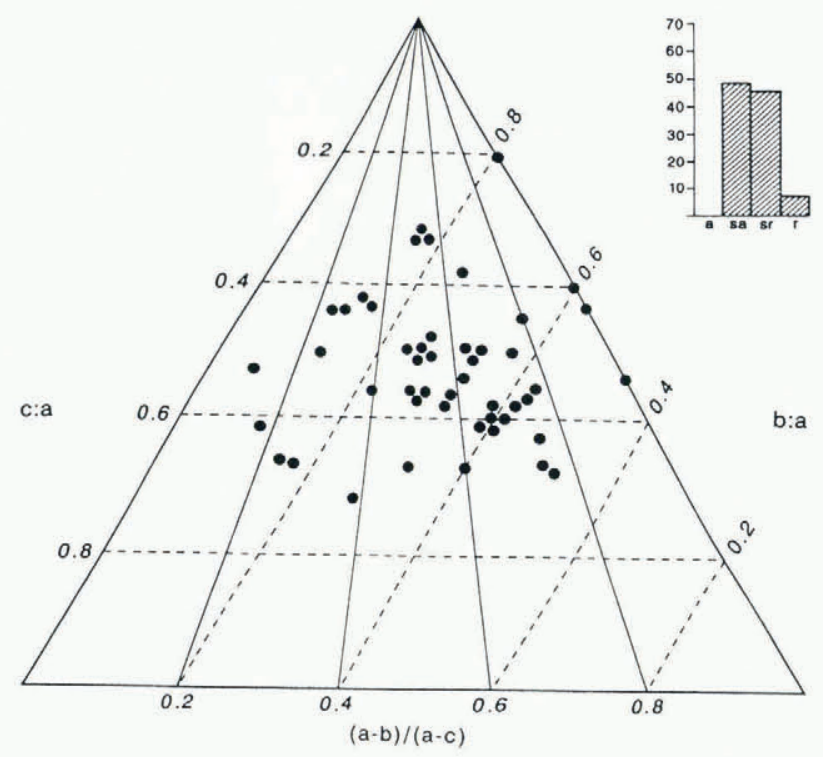

c
Table 1. Shape results from Matanuska Glacier compared with results from Slettmarkbreen, Norway (after Benn and Ballantyne, 1993)

Site $\quad C_{70} \quad R A$

Mat 1 -supraglacial debris $\quad 70 \quad 36$

Mat 2 inner moraine $\quad 46 \quad 0$

Mat 3 outer moraine $\quad 46 \quad 0$

$\begin{array}{lll}\text { Mat } 4 \text { ice-rich debris } & 30 & 0\end{array}$

Average supraglacial debris

(after Benn and Ballantyne, 1993) $\quad 70 \quad 86$

Average subglacial till

(after Benn and Ballantyne, 1993) $\quad 10 \quad 0$

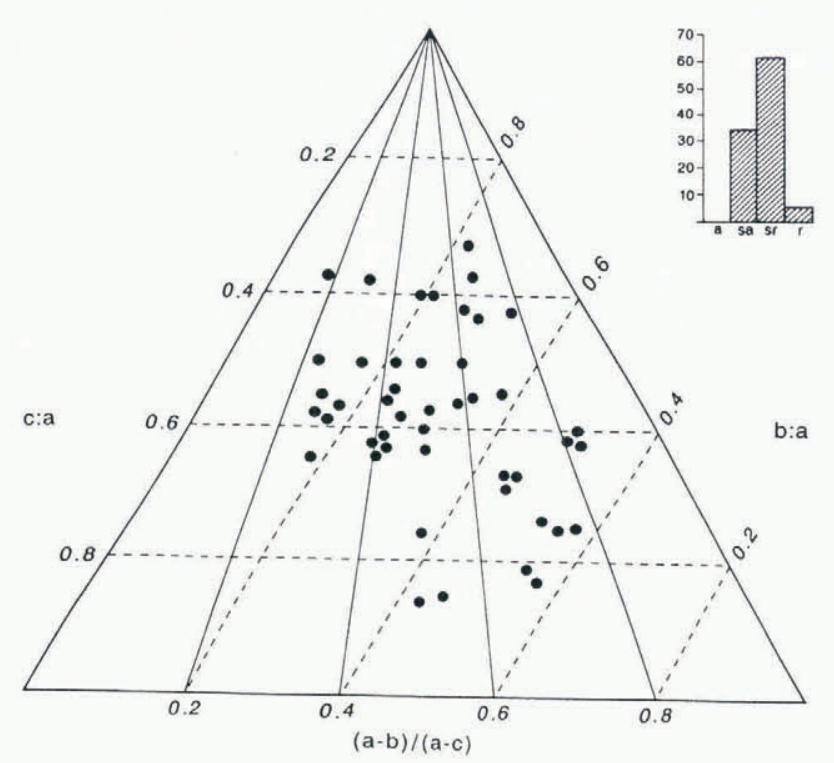

b

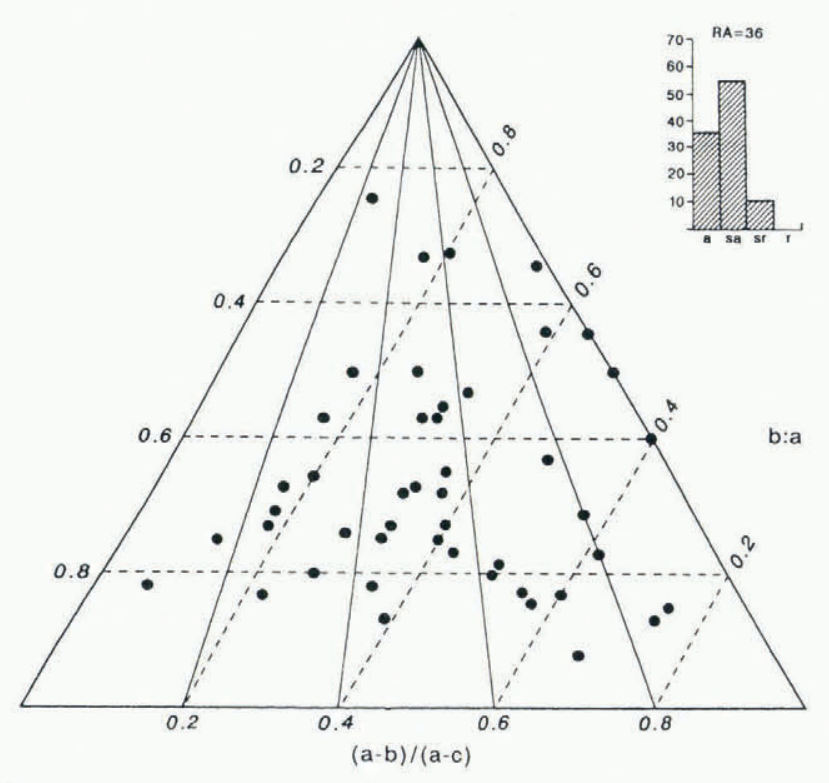

d

Fig. 6. Malanuska Glacier. Site 1: Particle-shape analysis. (a) Supraglacial debris; (b) Inner moraine; (c) Outer moraine; (d) Debris-rich ice. 
Table 2. Debris concentration in the debris-rich ice at Matanuska Glacier

\begin{tabular}{clrl}
\hline Sample & & $\%$ by weight & $\begin{array}{c}\text { Grain-size } \\
\mathrm{mm}\end{array}$ \\
& $\mathrm{kg}{ }^{-1}$ & & \\
\hline $1 \mathrm{a}$ & 0.0304 & 2.7 & 0.011 \\
$\mathrm{1b}$ & 0.1520 & 13.2 & 0.009 \\
$2 \mathrm{a}$ & 0.213 & 17.6 & 0.077 \\
$2 \mathrm{~b}$ & 1.93 & 59.1 & 0.00115 \\
\hline
\end{tabular}

whilst the ice-facies $\log$ (Fig. 5b) shows the nature of the BIL. This is more complex at this site than site 2 because of the steep dip. The debris-rich ice consists of layers of $(\mathrm{a})$ debris-poor ice; and (b) frozen debris, in differing amounts. At the base of the section there are thick bands of frozen debris (average $6 \mathrm{~mm}$ thick) separated by thin bands of debris-poor ice (average $1 \mathrm{~mm}$ thick), whilst at the top of the section there are thick bands of debris-poor ice $(10 \mathrm{~cm}$ thick $)$ with thin bands of frozen debris $(1 \mathrm{~cm}$ thick). Two samples were taken to calculate the concentration of sediments at this site: one in the middle (sample 1a) and one at the top (sample 1b) (results are shown in Table 2). The middle sample (1a) was taken from the debris-poor ice and has a concentration of $3 \%$ by weight, the upper sample taken from the debris/ratio of $1 / 10$ has a concentration of $13.2 \%$. The median grainsizes of these samples were as follows: sample la $=$ $0.011 \mathrm{~mm}$; sample $1 \mathrm{~b}=009 \mathrm{~mm}$. Fabrics were taken at the base, in the middle and at the top of the BIL. The results (shown in Figures $5 \mathrm{c}$ and 7 ; Table 3 ) show a general decrease in fabric strength upwards.

Site 2. Figure 8 a shows the nature of site 2. Here the beds are horizontal because the river is actively eroding away the front of the glacier. There are many structures seen within the BIL, including folds (Fig. 8a) and faults (Fig. 8b).

Ice-fabric measurements were also taken in this area but at different locations: one at the base of the section and a second at the upper junction (Fig. 8c). The results (Fig. 7 and Table 3 ) indicate that the ice fabrics are both relatively weak.
Figure $8 d$ shows the ice facies at site 2 . This shows a similar pattern to site 1 . At the base of the section there are thick bands of frozen debris $(6.5 \mathrm{~mm})$ and thin bands of debris-poor ice $(1 \mathrm{~mm}$ ) (sample 2a). Further up, the frozen debris bands and debris-poor bands are of similar thickness $(5 \mathrm{~mm}$ ) (sample $2 \mathrm{~b}$ ), then towards the top there are thicker bands of frozen debris and debris-poor ice, although the layers of debris-poor ice are always thicker. A debris concentration of $59 \%$ was found for the lower unit and $18 \%$ for the upper unit. The median grain-size of the two samples is as follows: sample $2 \mathrm{a}=0.077$; sample $2 \mathrm{~b}=0.00115$.

Interpretation of the moraines and preservation of the BIL when the ice melts

The particle-shape analysis showed that the supraglacial sediments were very angular, the subglacial sediments very rounded as expected, and the results were very similar to those from Slettmarkbreen, Norway, by Benn and Ballantyne (1993) (see Table 1). The moraines were very similar to one another and showed an intermediate shape but closer to the subglacial debris. Thus, the moraines were mostly composed of subglacial material but had a small input from clasts melting off the glacier surface. Because of the clear deformation seen in the moraines, I would suggest that these are push moraines but, because of the lack of any visual evidence for subglacial deformation, I suggest these moraines were formed purely by compression (bulldozing) (and not subglacial advection as was postulated at Exit and Childs Glaciers); during the summer when the ice retreats sediment builds up between the ice front and the moraine, then during the winter re-advance this is bulldozed. Using the same technique and assumptions as used for the other two glaciers, the volume produced in 1 year can be estimated, and at Matanuska Glacier site 1 this is $0.25 \mathrm{~m}^{3}$ year ${ }^{-1} \mathrm{~m}^{-1}$ over a $1 \mathrm{~m}$ section.

As described above, the melting of the BIL produced a very dynamic environment dominated by debris flows. Lawson (1979a) has described the development of meltout till due to the slow melting of the BIL. However, during the present study, no such observations were made and it seems very unlikely in such a dynamic environment that the ice could melt out and preserve its structures except in rare sites of low thermal conductivity.

Table 3. Ice-fabric results at Matanuska Glacier

\begin{tabular}{cccccr}
\hline \multicolumn{2}{c}{ Site } & Depth & S1 & S3 & Orientation \\
& & $\mathrm{m}$ & & \\
\hline \multirow{2}{*}{ Site 1 } & a-top & 0 & 0.634 & 0.143 & 94 \\
& b - middle & 1 & 0.591 & 0.056 & 167 \\
& c-base & 2 & 0.807 & 0.076 & 84 \\
Site 2 & a-top & 0 & & & 88 \\
& b-base & 8 & 0.649 & 0.024 & 141 \\
\hline
\end{tabular}




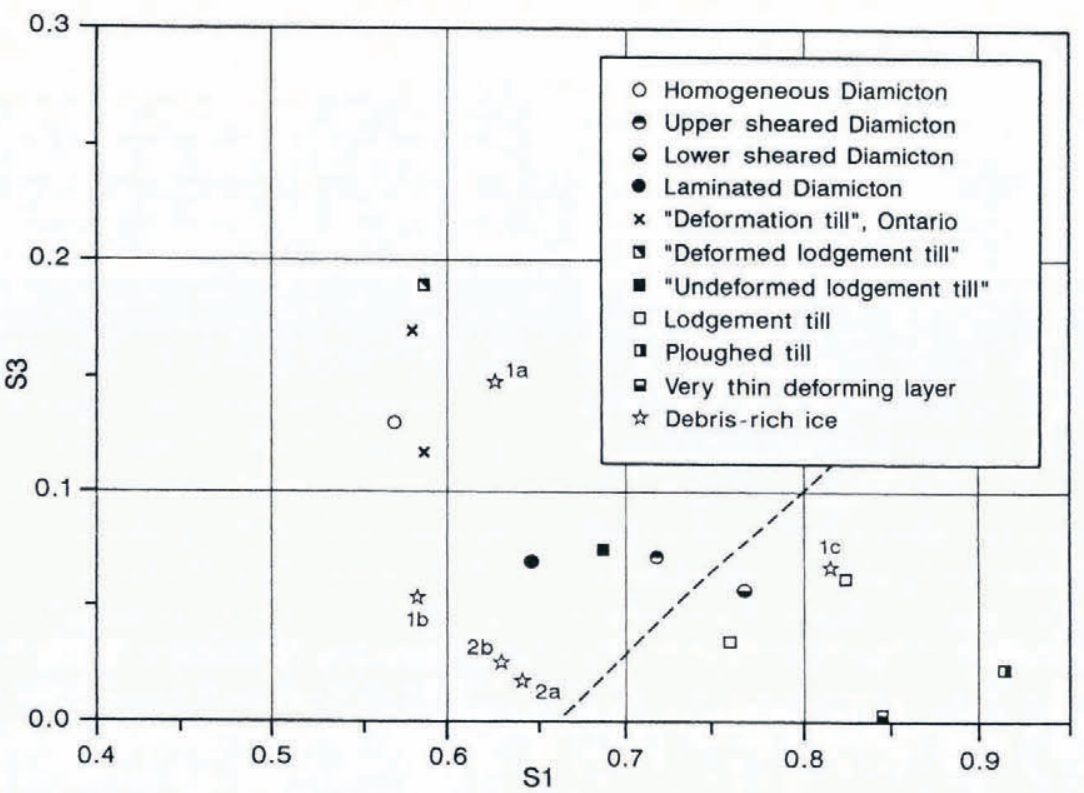

Fig. 7. Matanuska Glacier. Ice-fabric results, compared with other fabric dala from Hart (1994) and Dowdeswell and Sharp (1986). The dotted line marks the boundary between low fabric strength (above the line - typical of deforming-bed tills with a thick deforming layer) and high fabric strength (below the line - typical of lodgement tills and deforming-bed tills with a thin deforming layer).

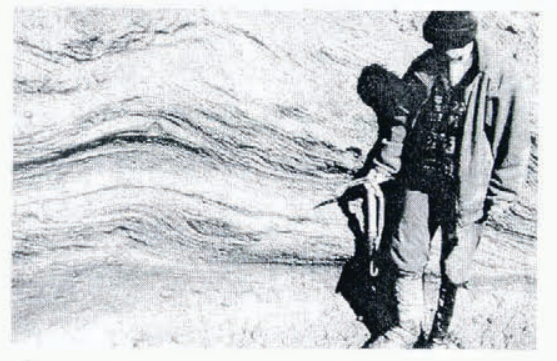

a

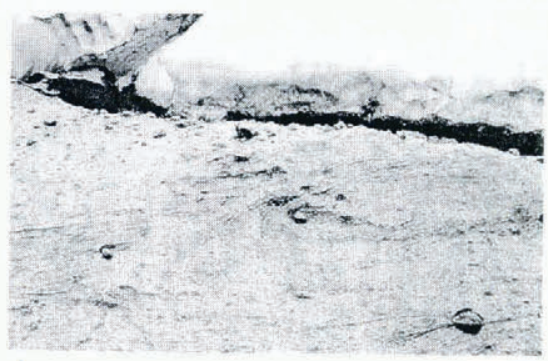

b

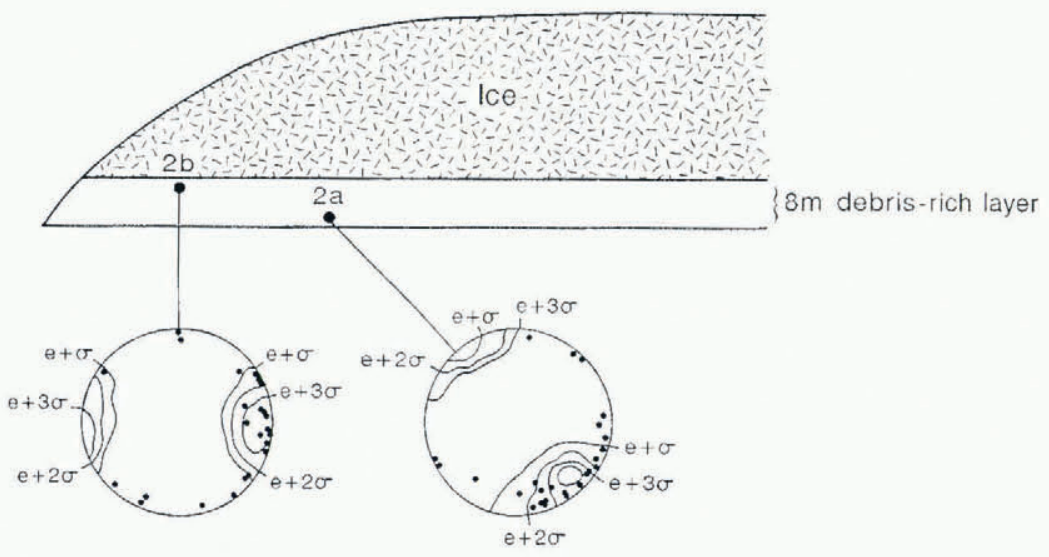

C

Fig. 8. Matanuska Glacier. Site 2. (a) Photograph of folding within the debris-rich ice; $(b)$ Photograph of faulting within the debris-rich ice; (c) Schematic diagram to show the location and results of the ice fabrics; (d) Ice-facies $\log$ and location of the samples taken for grain-size and concentration analysis.

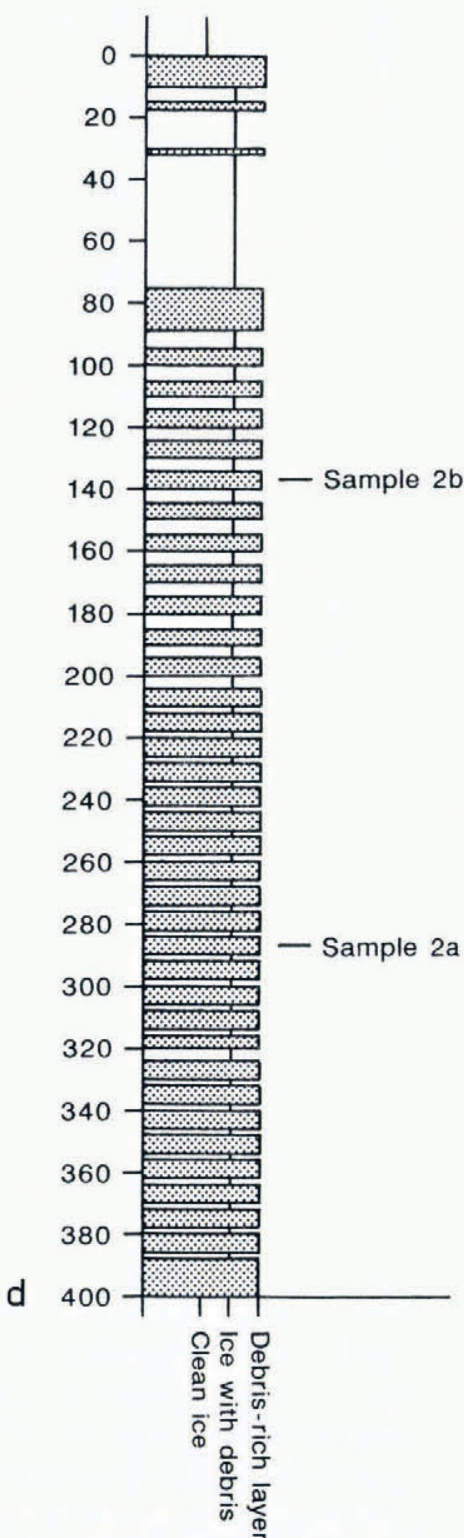




\section{DISCUSSION}

The three Alaskan glaciers which have been investigated were shown to have different bed conditions: Exit Glacier has a deforming bed with a clean ice base; Childs Glacier had a deforming bed but with a frozen top which was observed being sheared into the ice; and Matanuska Glacier which appeared to have no deforming layer but a thick deformed BIL. In order to understand the subglacial processes occurring in these three glaciers, the origin of the BIL at the base of Matanuska Glacier needs to be discussed in more detail. I will first compare the descriptions of ice facies from the literature with those seen at Matanuska Glacier then look at the different theories for debris entrainment and finally compare the results from the three glaciers.

\section{Ice facies}

A number of rescarchers have devised their own systems for describing ice facies; these systems can be summarized as follows (Lawson, 1979b; Knight, 1987): (1) stratified (or laminated) facies which are identified in both temperate and sub-polar glaciers $\mathrm{Kamb}$ and LaChapelle, 1964; Boulton, 1970) and (2) dispersed (or clotted) facies more commonly reported from sub-polar glaciers (Lawson, 1979b; Sugden and others, 1987). At Matanuska Glacier, Lawson (1979b) described two basal zones, an upper dispersed facies $0.2-8 \mathrm{~m}$ thick and a lower stratified facies $3-15 \mathrm{~m}$ thick. Sediment concentrations in the two zones were $0.05-8 \%$ and $0.0298 \%$, respectively. He suggested that the stratified facies consisted of three sub-facies: (a) discontinuous irregular aggregates of fine sediment; (b) suspended dispersed fine debris particles and aggregates and comprising the relatively clear zone between the more debris-rich layers; and (c) solid - bands of debris with interstitial ice. It is not clear how Lawson's dispersed facies is different from his discontinuous facies within the stratified facies, except he defined the former as containing no solid debris bands. However, Knight (1987) showed bands of debris within the dispersed (clotted) ice facies.

This is difficult to relate to the ice facies observed at Matanuska Glacier during this study. The BIL consisted of one distinct layer which was composed of a high debris/ ice ratio at the base and a low debris/ice ratio at the top. The individual debris couplets consisted of a debris-rich layer (equivalent to Lawson's solid layer) and a debrispoor layer. This debris-poor ice layer was equivalent to Lawson's suspended layer at the base but contained more debris particles towards the top (equivalent to Lawson's discontinuous facies).

Other researchers have noted the decrease in debris concentration upwards through the BIL, e.g. Boulton and others, (1979), Drewry (1986), Echelmeyer and Zongxiang (1987). Knight and others (1994) showed from four Greenland glaciers that the stratified and dispersed facies have similar mineral assemblage and particle shape but the dispersed facies is finer-grained and the clots within the dispersed facies decrease up ice. Knight (1987) has also suggested that dispersed facies (clotted ice) was found in areas of extending flow.

\section{Debris entrainment}

There have been a number of suggestions of how debris can be entrained within the BIL; this includes (Hubbard and Sharp, 1989; Hubbard, 1991; Tison and others 1993): (a) pressure-melting regelation (Weertman, 1957, 1964) around obstacles at the ice bed which usually produces debris layers with low debris/ice ratios separated by layers of clean ice; (b) adfreezing due to the oscillation of the freezing front in and out of saturated sediment (Weertman, 1961). It has been suggested that the debris/ ice couplets could represent a seasonal subglacial change in environment such as cold air entering the glacier (Andersen and others, 1982) or the penetration of the winter cold wave through thin ice (Boulton, 1977). Another possibility is a change in the nature of the subglacial sediment. Gow and others (1979) suggested that the clean ice formed over debris-free areas and the debris-rich formed over areas of soft sediment. It has been suggested that this process will produce debris layers with high debris/ice ratios (Sugden and others, 1987; Souchez and others, 1988); (c) shearing-in of debris (Goldthwaite, 1951; Dilabio and Shilts, 1979; Echelmeyer and Zhongxiang, 1987; Tison and others, 1993) which results in thin alternating layers of debris-rich and clean ice, and Tison and others reported low debris/ice ratios.

\section{Entrainment of the debris at the Alaskan glaciers}

At Childs Glacier, the deforming layer was incorporated into the ice by: (i) freezing-on by the migration of the freezing front passing down through saturated sediments and then (ii) shearing of this material into the glacier.

At Matanuska Glacier, the formation of the debrisrich layer is not so obvious. At this site, as at other debrisrich basal ice sites, the debris/ice ratio decreased upwards through the sequence; also the grain-size of the debris decreased upwards through the sequence. There is also evidence for deformation, including mylonization, and folding and faulting where there are local perturbations. The entrainment of the debris will be discussed in more detail below.

\section{Formation of the BIL}

Most researchers have then suggested that the stratified and dispersed facies have a different origin. Lawson (1979b) and Knight (1987, 1994) have suggested that the stratified facies was formed due to the freezing of meltwater and subglacial sediments to the glacier, and Knight (1994) suggested that the banded facies may be a deformed version of the stratified facies. Furthermore, Lawson (1979b) and Sugden and others (1987) have suggested that the dispersed facies is formed due to regelation sliding across a rough bed, whilst Knight (1987) suggested this facies is formed from debris-rich water being squeezed away from the bed into the adjacent vein network.

However, I suggest that all the facies within the BIL are formed in a similar manner and reflect different degrees of deformation. If sediment is initially entrained at the base of the ice due to adfreezing or regelation, as ice movement continues this will become both attenuated 
and moved upwards through the ice as more entrainment occurs beneath it. Thus, as deformation/ice movement continues, a thick debris band is attenuated into a thinner debris band, then into a clot and finally a debris particle. In this way, a debris-rich layer is transformed into a debris-poor layer as deformation increases upwards through the BIL. At the same time, debris may become finer, higher in the debris-rich layer, due to attrition between particles during both the high deformation and longer duration in the ice. A similar model to this was also proposed by Lavrushin (1970) and later discussed by Shaw (1977). They described the stratified facies of the BIL as the poorly attenuated facies and the dispersed facies the highly attenuated facies.

If it is assumed that the BIL is formed due to deformational processes, then a number of tentative estimations can be made:

(a) Changes in concentration of the debris-rich layers. Since many of the debris-rich layers at Matanuska Glacier were very thin, some of the debris-concentration measurements included both debris-rich and debrispoor bands. In order to calculate the debris concentrations of the debris-rich bands alone, the following calculation was undertaken. If it is assumed that the concentration of all the debris-poor ice is $2.7 \%$ as this was the debris/ice ratio minimum sample $1 \mathrm{~b})$ and where the debris/ice ratio is $6 / 1$ then overall concentration was $59 \%$ (debris/ice maximum - sample $2 \mathrm{~b}-300 \mathrm{~cm}$ down from top) then the concentration of the debris-rich bands would be $68 \%$. Using the same assumptions, at a depth of $150 \mathrm{~cm}$ where the debris/ice ratio is $5 / 5$, the concentration of the debris would be $33 \%$. Assuming that the debris at the base (which at this location was $400 \mathrm{~cm}$ ) was formed from adfreezing, it would have a debris concentration of $92 \%$ (as found at Childs Glacier). If this theoretical change in concentration is plotted (Fig. 9), it can be seen that the concentration decreases linearly upwards through the sequence $(y=13.6+4.2 x)$.

(b) Calculation of the amount of deformation (strain). If it assumed that the change in concentration is the result of deformation, then the strain at Matanuska Glacier can be estimated:

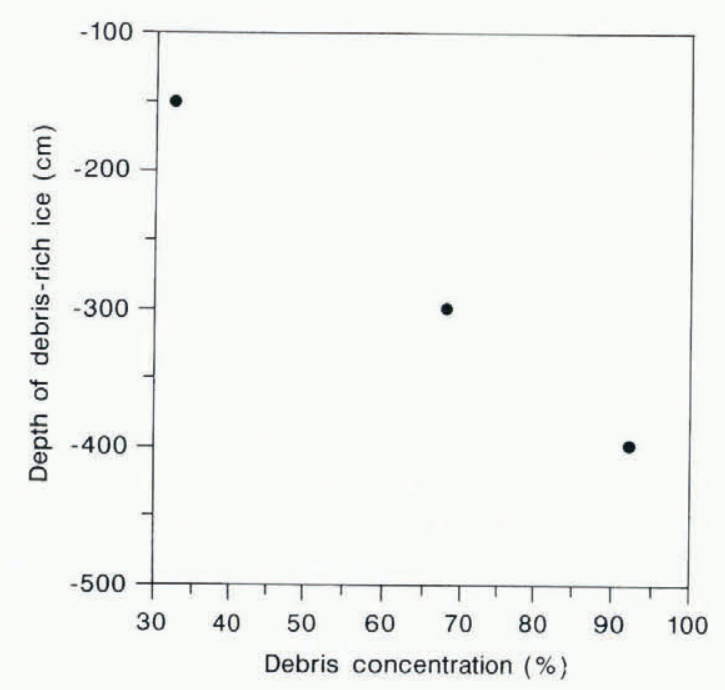

Fig. 9. Concentration at site $2 a$. $e=\frac{\text { Deformed concentration -- Original concentration }}{\text { Original concentration }} \times 100$.

Strain was calculated at Matanuska Glacier site 2a over the section using two techniques. First, strain was calculated on the basis of assuming the debris concentrations in the frozen debris layers were a constant $68 \%$ and in the debris-poor layers $2.7 \%$ (strain 1), and then more accurately using the results from Figure 10, whereby the debris concentration changed upwards through the sequence (strain 2). The results from this are shown in Table 4 and Figure 10a. Both techniques show a generally similar pattern of strain increasing towards the top; however, in the constant debris-concentration model (strain 1), the strain decreases in the top $60 \mathrm{~cm}$. The amount of strain in the strain 2 model is an order of magnitude greater than in the strain 1 model. I would suggest that the strain 2 model is probably more representative since preliminary results suggested a decrease in debris concentration with height; however, until the absolute concentrations in the debris-rich ice layers are measured, this remains only a suggestion.

Table 4. Change in strain in the ice facies at Malanuska Glacier site 2

\begin{tabular}{lrr}
\hline & \% strain 1 & $\%$ strain 2 \\
\hline $0-16 \mathrm{~cm}$ & 21 & 4779 \\
$16-30 \mathrm{~cm}$ & 387 & 2698 \\
$30-77 \mathrm{~cm}$ & 1365 & 2690 \\
$77-85 \mathrm{~cm}$ & 30 & 592 \\
$89-210 \mathrm{~cm}$ & 69 & 350 \\
$210-300 \mathrm{~cm}$ & 0 & 60 \\
$300-400 \mathrm{~cm}$ & 0 & 15 \\
\hline
\end{tabular}

Because of the observed and proposed deformation at Matanuska Glacier, it is difficult to say how the sediments were initially incorporated into the ice. It may have been by a similar process to that observed at Childs Glacier, that is initial freezing-on due to winter migration of the freezing front, followed by possible shearing-in. These annual adfreezing events may have accumulated at Matanuska Glacier (and not at Childs Glacier), because the former has a relatively stagnant margin at a high altitude $(500 \mathrm{ma}$ a.m.s.l.) whilst the latter has a lower/warmer $(0 \mathrm{~m}$ a.m.s.l.) advancing margin.

It can also be seen that at both sites at Matanuska Glacier the thicknesses of the debris-poor layers change in a similar manner (Figs $5 \mathrm{~b}$ and $8 \mathrm{~d}$ ), i.e. they increase in thickness upwards. If it is assumed that each year a couplet of debris-rich and debris-poor ice is formed, this increase in thickness (of the debris-poor layer) must be due to one of the following reasons: (i) the upper units result from larger initial couplets or (ii) since debris-rich ice and debris-poor ice have different rheological properties, the edges of the debris-rich layers are being 

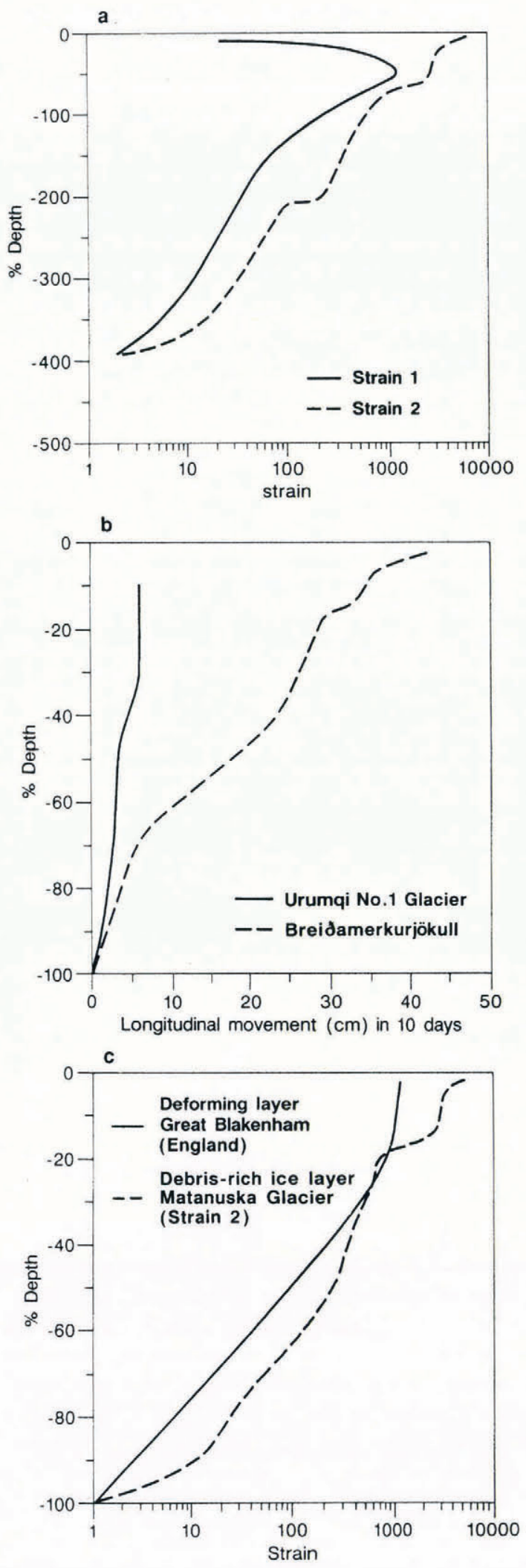

Fig. 10. (a) Strain at Matanuska Glacier site 2 using the two different concentrations (details explained in the text); (b) A comparison of displacement over $10 \mathrm{~d}$ within two types of subglacial environments: (i) Saturated deforming layer at Breidamerkurjökull, after Boulton (1979); (ii) Frozen debris at Urumqi No. 1 Glacier, after Echelmeyer and Zhangxiong (1987); (c) A comparison of longitudinal strain within two types of subglacial environment: (i) Saturated deforming layer at Great Blakenham, Suffolk, England, after Hart and Boulton (1991); (ii) Debris-rich ice layer at Matanuska Glacier (strain 2) site 2. incorporated into the debris-poor layers during deformation, so that the latter become thicker. Thus, at the top of the sequence the debris bands' ice will become completely incorporated (attenuated) into the debrispoor ice, except for particularly resistant layers. At site 2, there is a clast-rich lag at the top of the BIL. I suggest this latter explanation is more likely from the evidence at Matanuska Glacier but cannot be proved without comparisons with other sites.

If the latter explanation is true, then it is further field evidence that the debris-poor ice has a greater competence than debris-rich ice (see Hubbard and Sharp (1989) for detailed discussion of this problem). It also implies that the number of original couplets (years?) cannot be calculated, because the upper couplets have been completely broken down (attenuated) to form the debris-poor ice facies.

\section{Comparisons between the debris-rich layer and the deforming bed}

The interpretations I have made from the study of these three glaciers suggest to me that there are similarities between the debris-rich layer and the deforming layer. These are summarized in Table 5.

(a) Longitudinal deformation styles within the deforming layer (DL) and the BIL are very similar; these include shear strain and extension up-glacier (flutes and subglacial deformation $\{\mathrm{DL}\} /$ attenuation $\{B I L\})$ and compression at the margin (push moraines $\{D L\} /$ faulting and folding $\{B I L\})$.

(b) It has been suggested that deformation increases up through the basal layer. Echelmeyer and Zhongxiang (1987) recorded displacement in a frozen drift layer below the glacier. Similarly, Boulton (1979) recorded displacement in a deforming layer. The displacement over $10 \mathrm{~d}$ (taken from an average day multiplied by 10) is shown from these two sites in Figure 10b. It can be seen that the pattern of displacement is very similar but there is much faster movement in the deforming layer. Net longitudinal strain from the different subglacial environments can also be compared. It has been shown by Hart and Boulton (1991) that deformation increases upwards through the deforming layer and this is reflected in decreasing fabric strengths (Hart, 1994). It is very difficult to calculate strain in the subglacial deforming layer because: (a) there are few strain markers and (b) the thickness of the deforming layer changes as the glacier advances and retreats. One attempt has been made from a Quaternary site at Great Blakenham, England (Hart and Boulton, 1991). Figure 10c shows the results from the deforming layer compared with those from Matanuska Glacier, where fabric strengths also decreased upwards. It can be seen that the pattern of strain is very similar. It can also be argued that the style of deformation is similar; increases in strain within the deforming bed lead to the formation of a homogeneous diamicton (as all the components become mixed together); similarly, increases in strain in the BIL lead to the break-down of the debris-rich layers to form large units of debris-poor facies. 
Deforming bed

Exit Glacier

Glacier

Debris incorporation

Deformation styles

Fabric

Strain pattern

Contribution to ice flow

Annual sedimentation/

$1 \mathrm{~m}$ section

Sedimentary products upwards

Deforming bed/

frozen top

Childs Glacier

Adfreezing and shearing

Extensional and compressional

Decrease in strength

Increase in strain upwards 90\% Breiðamerkurjökull (Boulton, 1979)

$5 \mathrm{~m}^{3}$ year ${ }^{-1} \mathrm{~m}^{-1}$

Deforming bed till, flutes, push moraines
Extensional and compressional

$60 \%$ Urumqi No. 1 Glacier (Echelmeyer and Zhongxiang, 1987)

$3 \mathrm{~m}^{3}$ year $\mathrm{m}^{-1}$

Deforming bed till, push moraines
Debris-rich ice

Matanuska Glacier

Extensional deformation and adfreezing?

Extensional and compressional

Decrease in strength upwards

Increase in strain upwards

Main component of flow, Mount St. Helens (Brugman, 1983)

$0.25 \mathrm{~m}^{3}$ year $^{-1} \mathrm{~m}^{-1}$

Push moraines (bulldozing), debris flow deposits (c) Sediment incorporation into the basal layers is also similar. In the deforming layer it has been shown that sediments are incorporated by being sheared and folded into the base of the deforming layer due to perturbations but that material also melts in from the base of the glacier (Hart and Boulton, 1991). In the BIL, material is brought in by a combination of adfreezing (often down into a deforming layer) and shearing and folding due to perturbations.

(d) Measurements on the rate of subglacial sediment accumulations at the three glaciers showed that sedimentation at the two glaciers with a deforming bed was an order of magnitude higher than that with a debris-rich ice layer. It was also shown that Childs Glacier with its frozen top had a slightly lower sedimentation rate than Exit Glacier with full deforming-bed conditions even though this glacier was the smallest.

Thus, I suggest that the behaviour of the debris-rich ice layer is very similar to the deforming bed, except that the processes occur at a slower rate. Figure 11 a shows a schematic diagram of the different types of deforming layers observed at the three sites, although unfortunately it is not known how far these marginal conditions extend up-glacier. The ideas presented in this paper can be combined to produce an "ideal" glacier with a deforming bed and/or debris-rich base (Fig. 11b). This results in a series of décollement layers within the sequence, at the base of the deforming layer, at the ice sheet-sediment interface and the top of the debris-rich ice. The notion of a deforming bed/debris-rich ice continuum is useful because the processes of incorporation and deformation are similar in both types of deforming layers. However, I would also suggest that only the deforming bed remains in the geological record; in contrast, on melting the majority of the deformed BIL simply flows away to produce the complex sediment gravity-flow deposits described by Lawson (1979b, 1982).

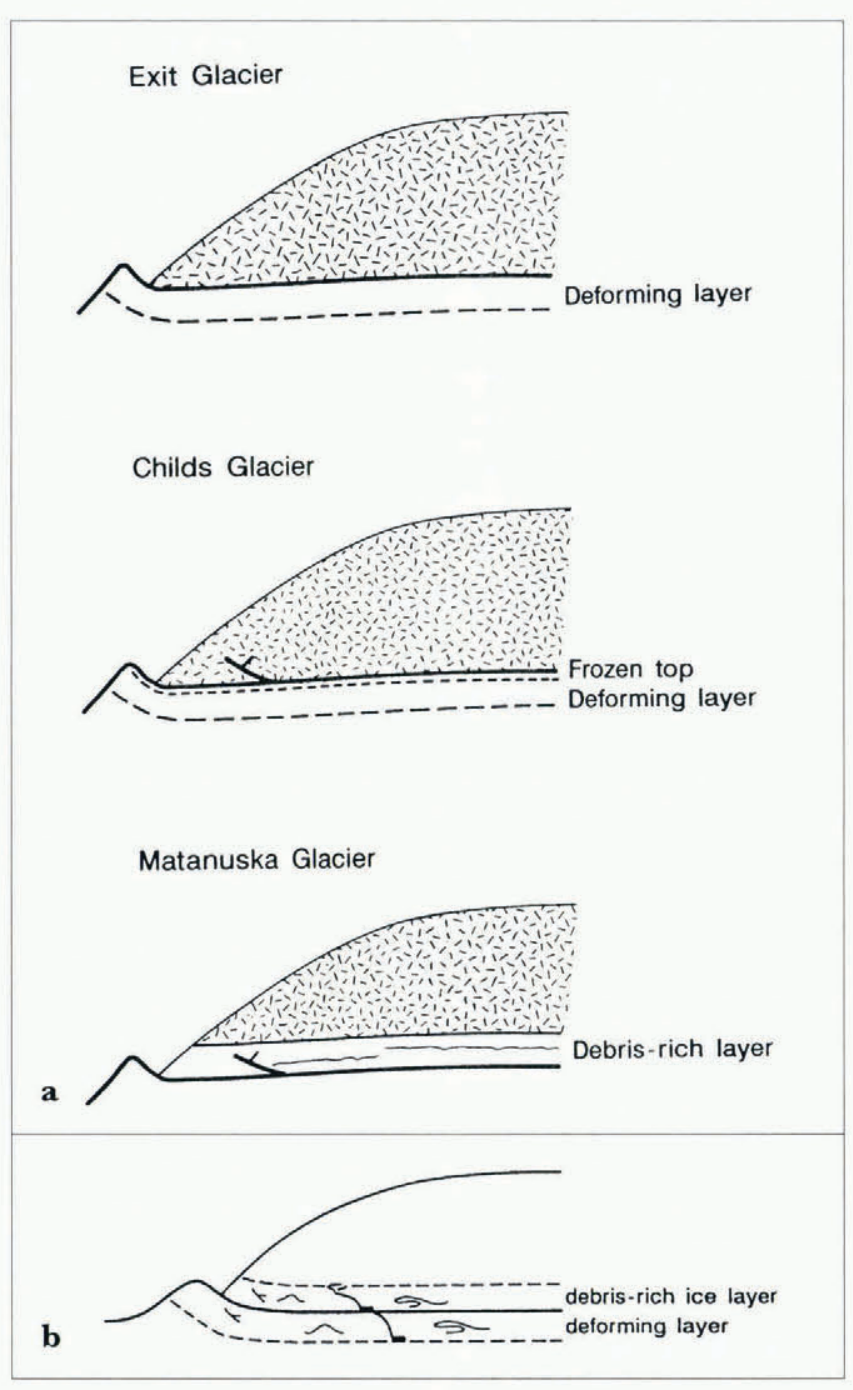

Fig. 11. (a) Schematic diagram to show the different types of deforming layers at the three sites; (b) Schematic diagram to show deforming bed/debris-rich ice continuum. 


\section{CONGLUSION}

It has been shown by a number of researchers that sediment at the base of the glacier, whether it is in the form of a saturated or frozen subglacial layer or debrisrich basal part of the glacier, can produce the most significant part of ice movement. Where the glacier moves over a deforming bed, subglacial sediment movement is very high and land forms from subglacial and proglacial deformation are produced. If the freezing front penetrates down into the deforming layer, deformation can still go on beneath and within the frozen layer. At the same time, the frozen top of the deforming laver can be incorporated further into the glacier by adfreezing and shearing. Subglacial sediment movement is still high although slightly lower than the unfrozen deforming layer. If the glacier is subjected to regular freezing-on events (such as winter cold penetration), then these debris-rich layers may both build up but become attenuated as the glacier moves. Although the debris-rich layer may increase the velocity of the glacier, this will be considerably less than those with a deforming bed and the resultant sediment accumulation is also much less.

Additionally, deformation patterns in the subglacial deforming bed are very similar to those within subglacial debris-rich ice, that is, fabrics become weaker upwards through the sequence and strain increases upwards through the sequence. Thus, this study has shown that there is a deforming bed/debris-rich continuum, whereby similar processes occur within the (a) saturated deforming layer; (b) frozen layer and (c) debris-rich ice layer. These three "deforming layers" will have a basal décollement surface but move at different rates. Sediment movement and thus strain is greatest in the saturated deforming layer and correspondingly decreases throughout the two upper layers. Similarly, only the subglacial products of the deforming layer have a chance of preservation within the geological record.

\section{ACKNOWLEDGEMENTS}

The photographs in this paper were taken by $\mathrm{K}$. Martinez, whom I should like to thank for his support and help in the field. I should also like to thank P. Calkin for advice about field sites and M. Tetreau, Seward Visitor Centre, for useful discussions about Exit Glacier. I should also like to thank A. Burn and his colleagues in the Cartographic Unit, Department of Geography, for their excellent figure reproduction, M. Hendy for proof reading, A. Hodson for concentration and grain-size analysis and R. Waller for discussions about the subject. This research was funded by U.K. Natural Environment Research Council grant GR9/991.

\section{REFERENCES}

Alley, R. B. 1988. Fabrics in polar ice sheets: development and prediction. Science, 240 (4851), 493-495.

Alley, R. B., D. D. Blankenship, C. R. Bentley and S. T. Rooney. 1986. Deformation of till beneath Ice Stream B, West Antarctica. Nature, $322(6074), 57-59$.

Anderson, R.S., B. Hallet, J. Walder and B. F. Aubrey. 1982.
Observations in a cavity beneath Grinnell Glacier. Earth Surface Processes and Landforms, 7, 63-70.

Benn, D. I. and C.K. Ballantyne. 1993. The description and representation of particle shape. Earth Surface Processes and Landforms, $\mathbf{1 8}(7), 665-672$.

Boulton, G. S. 1970. On the origin and transport of englacial debris in Svalbard glaciers. \%. Glaciol., 9 (56), 213-229.

Boulton, G.S. 1976. The origin of glacially fluted surfaces observations and theory. 7. Glaciol., 17 (76), 287-309.

Boulton, G.S. 1977. Guide to Breidamerkurjökull, Iceland. INQUA, Commission on Lithology and Genesis of Quaternary Deposits, Iceland.

Boulton, G. S. 1979. Processes of glacier erosion on different substrata. , f. Glaciol., $23(89), 15-38$.

Boulton, G.S. 1986. Push moraines and glacier-contact fans in marine and terrestrial environments. Sedimentology, 33(5), 677-698.

Boulton, G. S. and R.C. A. Hindmarsh. 1987. Sediment deformation beneath glaciers: rheology and geological consequences. f. Geophys. Res., 92 (B9), 9059-9082.

Boulton, G.S. and A.S. Jones. 1979. Stability of temperate ice caps and ice sheets resting on beds of deformable sediment. J. Glaciol., 24(90), 2944.

Boulton, G.S., E. M. Morris, A. A. Armstrong and A. Thomas. 1979. Direct measurement of stress at the base of a glacier. F. Glaciol., $232(86), 3-24$

Boulton, G.S. and 9 others. 1989. Preliminary report on Glaciotecs '84. University of Amsterdam, Amsterdam. Fysisch Geografisch en Bodemkundig Laboratorium.

Brugman, M. M. 1983. Properties of debris-laden ice: applications to the flow response of the glaciers on Mount St Helens. Ann. Glaciol., 4, 297.

Calkin, P. E. 1988. Holocene glaciation of Alaska (and adjoining Yukon Territory, Canada). Quat. Sci. Rev., 7 2), 159-184.

Connor, C. and D. O'Haire. 1988. Roadside geology of Alaska. Missoula, MT, Mountain Press Publishing Company.

Dilabio, R. N. W. and W. W. Shilts. 1979. Composition and dispersal of debris by modern glaciers, Bylot Island, Canada. In Schlüchter, C., ed. Moraines and varves: origin, genesis, classification. Rotterdam, Balkema, 145-155.

Dowdeswell, J. A. and M.J. Sharp. 1986. Characterization of pebble fabrics in modern terrestrial glacigenic sediments. Sedimentology, $33(5), 699-710$.

Drewry, D. 1986. Glacial geologic processes. London, Edward Arnold.

Echelmeyer, K. and Wang Zhongxiang. 1987. Direct observation of basal sliding and deformation of basal drift at sub-freezing temperatures. J. Glaciol., 33(113), 8998.

Ferguson, S. A. 1992. Glaciers of North America; a field guide. Golden, CO, Fulcrum Publishing

Goldthwait, R. P. 1951. Development of end moraines in east-central Baffin Island. J. Geol., $59(6), 567-577$.

Gow, A. J., S. Epstein and W. Sheehy. 1979. On the origin of stratified debris in ice cores from the bottom of the Antarctic ice sheet. $f$. Glaciol., 23 (89), 185-192.

Hart, J. K. 1990. Proglacial glaciotectonic deformation and the origin of the Cromer Ridge push moraine complex, north Norfolk, England. Boreas, $19(2), 165-180$.

Hart, J. K. 1994. Till fabric associated with deformable beds. Earth Surface Processes and Landforms, 19 1), 15-32.

Hart, J.K. 1995. Recent drumlins, flutes and lineations at VestariHagafellsjökull, Iceland. f. Glaciol., 41(139), 596-606.

Hart, J. K. and G.S. Boulton. 1991. The interrelation of glaciotectonic and glaciodepositional processes within the glacial environment. Quat. Sci. Rev., 10(4), 335-350.

Hart, J. K. and D. H. Roberts. 1994. Crieteria to distinguish between subglacial glaciotectonic and glaciomarine sedimentation, I. Deformation styles and sedimentology. Sediment. Geol., 91(1-4), 191-213.

Hicock, S. R. and A. Dreimanis, 1992. Deformation till in the Great Lakes region: implications for rapid flow along the south-central margin of the Laurentide ice sheet. Can. J. Earth Sci., 29(7), 1565 1579 .

Hubbard, B. 1991. Freezing-rate effects on the physical characteristics of basal ice formed by net adfreezing. f. Glaciol., 37 (127), 339-347.

Hubbard, B. and M. Sharp. 1989. Basal ice formation and deformation: a review. Progress in Physical Geography, 13 4), 529-558.

Hudleston, P.J. 1983. Strain patterns in an ice cap and implications for strain variations in shear zones. J. Struct. Geol., 5(3-4), 455463.

Kamb, B. and E. LaChapelle. 1964. Direct observation of the mechanism of glacier sliding over bedrock. J. Glaciol., 5 (38), 159-172.

Knight, P. G. 1987. Observations at the edge of the Greenland ice sheet: boundary condition implications for modellers. International Association 
of Hydrological Sciences Publication 170 (Symposium at Vancouver 1987 The Physical Basis of Ice Sheet Modelling), 359-366.

Knight, P. G. 1992. Ice deformation very close to the ice-sheet margin in West Greenland. 7. Glaciol., 38(128), 3-8.

Knight, P. G. 1994. Two-facies interpretation of the basal layer of the Greenland ice sheet contributes to a unified model of basal ice formation. Geology, 22(11), 971-974.

Lavrushin, Yu. A. 1970. Reflection of the dynamics of glacier movement in the structure of ground moraine. Litol. Polezn. Iskop., 6, 115-120 [in Russian].

Lawson, D. E. 1979a. A comparison of the pebble orientations in ice and deposits of the Matanuska Glacier, Alaska. f. Geol., 87 (6), 629645.

Lawson, D.E. 1979b. A sedimentological analysis of the western terminus region of the Matanuska Glacier. CRREL Rep. 79-9.

Lawson, D. E. 1982. Mobilization, movement and deposition of active subaerial sediment flows, Matanuska Glacier, Alaska. J. Geol., 90 (3), $279-300$.

Mark, D. M. 1973. Analysis of axial orientation data, including till fabrics. Geol. Soc. Am. Bull., 84(4), 1369-1374.

Péwé, T. L. 1975. Quaternary geology of Alaska. U.S. Geol. Surv. Prof. Pap. 835.

Post, A. and M.F. Meier. 1980. A preliminary inventory of Alaskan glaciers. International Association of Hydrological Sciences Publication 126 Riederalp Workshop 1978 - World Glacier Inventory), 45-47.

Price, R.J. 1970. Moraines at Fjallsjökull, Iceland. Arct. Alp. Res., 2(1), $27-42$.

Rice, B. 1975. Changes in the Harding Icefield, Kenai Peninsula, Alaska. M.Sc. thesis, University of Alaska, Fairbanks. School of Agriculture and Land Resources.

Sharp, M. 1984. Annual moraine ridges at Skálafellsjökull, south-east
Iceland. f. Glaciol., 30 (104), 8293.

Sharp, M. 1988. Surging glaciers: geomorphic effects. Prog. Phys, Geogr., $12(4), 533-559$.

Sharp, M., J. Jouzel, B. Hubbard and W. Lawson. 1994. The character, structure and origin of the basal ice layer of a surge-type glacier. $\mathcal{J}$. Glaciol., 40 (135), 327-340.

Shaw, J. 1977. Tills deposited in arid polar environments. Can. J. Earth Sci., 14 6), 1239-1245.

Sneed, E. D. and R. L. Folk. 1958. Pebbles in the lower Colorado River, Texas; a study in particle morphogenesis, f. Geol., 66, 114 150.

Souchez, R. A., R. Lorrain, J. -L. Tison and J. Jouzel. 1988. Co-isotopic signature of two mechanisms of basal-ice formation in Arctic outlet glaciers. Ann. Glaciol., 10, 163-166.

Sugden, D.E. and 6 others, 1987. Evidence for two zones of debris entrainment beneath the Greenland ice sheet. Nature, 328(6127), $238-241$.

Tison, J.-L., J.-R. Petit, J.-M. Barnola and W. C. Mahaney. 1993. Debris entrainment at the ice-bedrock interface in sub-freezing temperature conditions (Terre Adélie, Antarctica). J. Glaciol., 39 (132), 303-315.

Weertman, J. 1957. On the sliding of glaciers. J. Glaciol., 3 21), 33-38.

Weertman, J. 1961. Mechanism for the formation of inner moraines found near the edge of cold ice caps and ice sheets. F. Glaciol., 3 (30), $965-978$.

Weertman, J. 1964. The theory of glacier sliding. f. Glaciol., 5(39), 287303.

Wiles, G. C. and P.E. Calkin. 1994. Late Holocene, high resolution glacial chronologies and climate, Kenai Mountains, Alaska. Geol. Soc. Am. Bull., $106(2) 03$.

MS received 20 January 1995 and accepted in revised form 19 June 1995 